\title{
An Investigation of Fractal Characteristics of Marine Shales in the Southern China from Nitrogen Adsorption Data
}

\author{
Jian Xiong, ${ }^{1}$ Xiangjun Liu, ${ }^{1,2}$ and Lixi Liang ${ }^{2}$ \\ ${ }^{1}$ School of Geoscience and Technology, Southwest Petroleum University, Chengdu 610500, China \\ ${ }^{2}$ State Key Laboratory of Oil and Gas Reservoir Geology and Exploitation, Southwest Petroleum University, Chengdu 610500, China \\ Correspondence should be addressed to Jian Xiong; 361184163@qq.com
}

Received 3 April 2015; Accepted 29 July 2015

Academic Editor: Talhi Oualid

Copyright (c) 2015 Jian Xiong et al. This is an open access article distributed under the Creative Commons Attribution License, which permits unrestricted use, distribution, and reproduction in any medium, provided the original work is properly cited.

\begin{abstract}
We mainly focus on the Permian, Lower Cambrian, Lower Silurian, and Upper Ordovician Formation; the fractal dimensions of marine shales in southern China were calculated using the FHH fractal model based on the low-pressure nitrogen adsorption analysis. The results show that the marine shales in southern China have the dual fractal characteristics. The fractal dimension $D_{1}$ at low relative pressure represents the pore surface fractal characteristics, whereas the fractal dimension $D_{2}$ at higher relative pressure describes the pore structure fractal characteristics. The fractal dimensions $D_{1}$ range from 2.0918 to 2.718 with a mean value of 2.4762, and the fractal dimensions $D_{2}$ range from 2.5842 to 2.9399 with a mean value of 2.8015 . There are positive relationships between fractal dimension $D_{1}$ and specific surface area and total pore volume, whereas the fractal dimensions $D_{2}$ have negative correlation with average pore size. The larger the value of the fractal dimension $D_{1}$ is, the rougher the pore surface is, which could provide more adsorption sites, leading to higher adsorption capacity for gas. The larger the value of the fractal dimension $D_{2}$ is, the more complicated the pore structure is, resulting in the lower flow capacity for gas.
\end{abstract}

\section{Introduction}

With the increase of the global energy demands and the importing of advanced techniques, the unconventional gas reservoirs (including tight sands, coal bed methane, and shale gas) have gradually been the focus of exploration and development in many countries such as Canada, China, and Europe [1, 2], especially in China [3]. Shale gas, as one kind of unconventional gas reservoirs, is not only an important energy supplement but also a clean and green energy. In 2011, the "World Shale Gas Resources: An Initial Assessment of 14 Regions Outside the United States," conducted by the U.S. DOE's Energy Information Administration, evaluates the risk technically recoverable of shale gas resource to be $36.1 \times 10^{8} \mathrm{~m}^{3}$ in China and $19.6 \times 10^{8} \mathrm{~m}^{3}$ in Sichuan Basin, located in Southwest China [4]. And according to "the nation survey and devaluation of shale gas resource and favorable area selection," issued by the Ministry of Land and Resources of the People's Republic of China, the risk technically recoverable of shale gas reservoir is estimated to be approximately $25.08 \times 10^{12} \mathrm{~m}^{3}$ in China and $14.58 \times 10^{12} \mathrm{~m}^{3}$ in southern China. Some studies also suggested that there is a great development potential of shale gas resources in southern China $[3,5]$.

To reduce exploration risk and determine economic feasibility, considerable efforts are being undertaken to understand the knowledge of storage mechanism of shale gas and transport mechanisms of shale gas $[6,7]$, and pore structure of shale has a significant influence on storage mechanism and transport mechanisms. Therefore, the complex pore structure of shale is an important research field. To understand the complex pore structure of marine shales in southern China, researchers have utilized several measurement techniques to characterize the characteristics of pore structure of marine shales in southern China. Many methods such as scanning electron microscopy, field emission scanning electron microscopy, transmission electron microscopy, focused ion beam scanning electron microscopy, low-pressure gas adsorption analyses, mercury injection capillary pressure, and small-angle neutron scattering have been used to investigate characteristics of pore structure [616]. Among these, low-pressure nitrogen $\left(\mathrm{N}_{2}\right)$ adsorption 
TABLE 1: Shale samples properties.

\begin{tabular}{|c|c|c|c|c|}
\hline Region & Number & Age/formation & Types & Source \\
\hline \multirow{6}{*}{$\begin{array}{l}\text { Changning- } \\
\text { Xingwen area, } \\
\text { Sichuan } \\
\text { Province }\end{array}$} & $\mathrm{L} 1$ & \multirow{18}{*}{$\begin{array}{l}\text { Lower Silurian } \\
\text { Longmaxi } \\
\text { Formation }\end{array}$} & \multirow{6}{*}{ Core } & \multirow{6}{*}[1,8]{} \\
\hline & $\mathrm{L} 2$ & & & \\
\hline & L3 & & & \\
\hline & $\mathrm{L} 4$ & & & \\
\hline & L5 & & & \\
\hline & L6 & & & \\
\hline \multirow{7}{*}{$\begin{array}{l}\text { Changning } \\
\text { area, Sichuan } \\
\text { Province }\end{array}$} & L7 & & \multirow{7}{*}{ Core } & \multirow{7}{*}{ In this study } \\
\hline & L8 & & & \\
\hline & L9 & & & \\
\hline & L10 & & & \\
\hline & L11 & & & \\
\hline & L12 & & & \\
\hline & L13 & & & \\
\hline \multirow{5}{*}{$\begin{array}{l}\text { Shizhu area, } \\
\text { Chongqing }\end{array}$} & L14 & & \multirow{5}{*}{ Outcrop } & \multirow{5}{*}{ In this study } \\
\hline & L15 & & & \\
\hline & L16 & & & \\
\hline & L17 & & & \\
\hline & L18 & & & \\
\hline \multirow{4}{*}{$\begin{array}{l}\text { Wuhu area, } \\
\text { Anhui } \\
\text { Province }\end{array}$} & G1 & & \multirow{4}{*}{ Core } & \multirow{4}{*}[11]{} \\
\hline & G2 & Gufeng & & \\
\hline & G3 & Formation & & \\
\hline & G4 & & & \\
\hline \multirow{5}{*}{ Sichuan Basin } & N1 & \multirow{5}{*}{$\begin{array}{l}\text { Lower Cambrian } \\
\text { Niutitang } \\
\text { Formation }\end{array}$} & \multirow{5}{*}{ Core } & \multirow{5}{*}[7,13,14]{} \\
\hline & $\mathrm{N} 2$ & & & \\
\hline & $\mathrm{N} 3$ & & & \\
\hline & $\mathrm{N} 4$ & & & \\
\hline & N5 & & & \\
\hline \multirow{7}{*}{$\begin{array}{l}\text { Well } \\
\text { Yuke 1, } \\
\text { southern } \\
\text { Chongqing }\end{array}$} & N6 & & \multirow{12}{*}{ Core } & \multirow{12}{*}[10,15]{} \\
\hline & N7 & & & \\
\hline & N8 & & & \\
\hline & N9 & & & \\
\hline & N10 & Lower Cambrian & & \\
\hline & N11 & Niutitang & & \\
\hline & $\mathrm{N} 12$ & Formation & & \\
\hline \multirow{5}{*}{$\begin{array}{l}\text { Well } \\
\text { Youke 1, } \\
\text { southern } \\
\text { Chongqing }\end{array}$} & N13 & & & \\
\hline & N14 & & & \\
\hline & N15 & & & \\
\hline & N16 & & & \\
\hline & N17 & & & \\
\hline \multirow{7}{*}{$\begin{array}{l}\text { Qilongcun } \\
\text { section, Xishui } \\
\text { contry, } \\
\text { Guizhou } \\
\text { Province }\end{array}$} & WL1 & Upper & \multirow{7}{*}{ Outcrop } & \\
\hline & WL2 & Ordovician & & \\
\hline & WL3 & Wufeng & & \\
\hline & WL4 & Formation- & & [24] \\
\hline & WL5 & Longmaxi & & \\
\hline & WL6 & Formation & & \\
\hline & WL7 & & & \\
\hline
\end{tabular}

TABLE 1: Continued.

\begin{tabular}{|c|c|c|c|c|}
\hline Region & Number & Age/formation & Types & Source \\
\hline & WL8 & & & \\
\hline & WL9 & & & \\
\hline & WL10 & & & \\
\hline & WL11 & & & \\
\hline & WL12 & & & \\
\hline & WL13 & & & \\
\hline & WL14 & & & \\
\hline
\end{tabular}

analysis had been proven to be an effective method to characterize pore structures of shale [10-16]. In addition, the $\mathrm{N}_{2}$ adsorption data had also been used to investigate the fractal characteristics of sands or coals [17-20]. There are only few reports on the fractal characteristics of shales from the Lower Cambrian Niutitang Formation in Sichuan Basin of China [7] and from the Chang-7 of the Upper Triassic Yanchang Formation in the Ordos Basin of China [16].

Compared with the extensive investigations on the fractal characteristics of sandstones and coals [17-22], similar studies on the fractal characteristics of shale in China have only received attention in recent years $[7,16]$. There are several sets of marine shales with rich organic matter in southern China, including the Lower Cambrian, Upper Ordovician, Lower Silurian, and Lower Permian shale $[5,23]$, and those shale gas reservoirs in southern China are regarded as the main area for shale gas development $[3,23]$. The objectives of the paper are to apply the fractal theory to investigate the irregularity of pore structure and study the fractal characteristics of marine shales in southern China based on the nitrogen adsorption analysis. And a parameter, fractal dimension, can be adopted to describe the fractal characteristics, which was calculated by the fractal Frenkel-Halsey-Hill (FHH) model from the $\mathrm{N}_{2}$ adsorption data. Meanwhile, the relationships between pore structure parameters and fractal dimension have been investigated, and the relationships between fractal dimension and adsorption capacity and flow capacity of shale are also discussed. It was anticipated that our research provides the critical data presenting the fractal characteristics of the marine shales in southern China and understanding the influence of the fractal dimension on the adsorption capacity and flow capacity of the marine shales in southern China.

\section{Samples and Methods}

In order to investigate the fractal characteristics of marine shales with rich organic matter in southern China, four geological ages and formations are selected for the research objects, including the Lower Cambrian Niutitang Formation, Upper Ordovician Wufeng Formation, Lower Silurian Longmaxi Formation, and Lower Permian Gufeng Formation. The sample number, age, formation, and types are shown in Table 1. Part of shale samples is obtained from the Lower Silurian Longmaxi Formation in Changning area of Sichuan Province and Shizhu area of Chongqing, located in southern 
China. And the obtained samples were characterized by lowpressure $\mathrm{N}_{2}$ adsorption analysis and permeability analysis. In addition, more detailed information on low-pressure $\mathrm{N}_{2}$ adsorption analysis, permeability analysis, and high-pressure methane adsorption analysis of the other part of shale samples can be gained in $[1,7,8,10,11,13-15,24]$.

Low-pressure $\mathrm{N}_{2}$ adsorption analysis was measured on a Quadrasorb SI Surface Area Analyzer and Pore Size Analyzer at the temperature of liquid nitrogen following Chinese National Standard (GB/T) 19587-2004 and (GB/T) 21650.22008. Shale samples were crushed to grains of 60-80 mesh size and then outgassed at $378 \mathrm{~K}$ for $24 \mathrm{~h}$. For all samples, nitrogen adsorption isotherms at $77 \mathrm{~K}$ were measured for the relative pressure ranging from 0.01 to 0.99 . The specific surface area was calculated using the Brunauer-EmmettTeller (BET) method [25], and the total pore volume was estimated to be the liquid volume of nitrogen at a relative pressure of 0.98 .

The permeability of core plug samples was measured following the Chinese Oil and Gas Industry Standard (SY/T) 5336-1996. Permeability measurements were conducted using a pulse-decay permeability measurement (Low Gas Permeability Measurement 700) with nitrogen as the medium.

Fractal analysis can be used to describe the geometric and structural properties of the solid surface [26, 27], and the quantitative evaluation of the fractal geometry was to use a parameter, the fractal dimension $D$, which was used as an index of pore surface roughness or pore structure complexity of the solid [27]. That is to say, the solid with more fractal dimension $D$ has more complicated pore structure or irregular pore surface. Based on the $\mathrm{N}_{2}$ adsorption data, the fractal dimension can be determined by applying the FrenkelHalsey-Hill (FHH) equation [27], and the FHH model can be described as follows $[22,27,28]$ :

$$
\ln (V)=(D-3) \ln \left(\ln \left(\frac{p_{0}}{p}\right)\right)+\text { constant, }
$$

where $V$ is the volume of $\mathrm{N}_{2}$ adsorbed at each equilibrium pressure $p ; p_{0}$ is the saturation pressure; and $D$ is the fractal dimension. Thus, according to the fractal FHH model, a plot of $\ln (V)$ versus $\ln \left(\ln \left(p_{0} / p\right)\right)$ shows a linear relationship, and the slope may be used to calculate the fractal dimension $D$.

\section{Results and Discussions}

3.1. Pore Structure Parameters and Permeability. The results from the low-pressure $\mathrm{N}_{2}$ adsorption analysis are shown in Table 2. From Table 2, we observe that pore structure parameters of marine shales in southern China exhibit a wide range. The specific surface area calculated from the $\mathrm{N}_{2}$ adsorption data using the BET model ranges from 1.6545 to $32.5015 \mathrm{~m}^{2} / \mathrm{g}$ with a mean value of $15.4417 \mathrm{~m}^{2} / \mathrm{g}$. The nitrogen adsorption volume at $p / p_{0}$, about 0.98 , can be used to estimate total pore volume and mean pore size. The total pore volume varies from 0.00195 to $0.04374 \mathrm{~cm}^{3} / \mathrm{g}$ with an average of $0.00209 \mathrm{~cm}^{3} / \mathrm{g}$, and average pore size generally is in the range of 3.567-9.723 nm with an average of $5.7215 \mathrm{~nm}$, which belongs to mesopore according to the International Union
TABLE 2: Pore structure parameters of shale samples from $\mathrm{N}_{2}$ adsorption isotherms.

\begin{tabular}{|c|c|c|c|c|}
\hline Number & $\begin{array}{c}\text { Total pore } \\
\text { volume } \\
\left(\mathrm{cm}^{3} / \mathrm{g}\right)\end{array}$ & $\begin{array}{c}\text { Specific } \\
\text { surface area } \\
\left(\mathrm{m}^{2} / \mathrm{g}\right)\end{array}$ & $\begin{array}{c}\text { Monolayer } \\
\text { volume } \\
\left(\mathrm{cm}^{3} / \mathrm{g}\right)^{\mathrm{a}}\end{array}$ & $\begin{array}{c}\text { Average } \\
\text { pore size } \\
(\mathrm{nm})^{\mathrm{b}}\end{array}$ \\
\hline L1 & 0.03074 & 18.821 & 0.006685 & 6.532 \\
\hline L2 & 0.03313 & 16.509 & 0.005864 & 8.028 \\
\hline L3 & 0.02744 & 19.592 & 0.006959 & 5.602 \\
\hline L4 & 0.02246 & 15.593 & 0.005539 & 5.762 \\
\hline L5 & 0.02297 & 9.885 & 0.003511 & 9.296 \\
\hline L6 & 0.02823 & 16.881 & 0.005996 & 6.690 \\
\hline L7 & 0.01263 & 7.147 & 0.002539 & 7.069 \\
\hline L8 & 0.01176 & 6.354 & 0.002257 & 7.404 \\
\hline L9 & 0.01417 & 7.991 & 0.002839 & 7.095 \\
\hline L10 & 0.01602 & 12.458 & 0.004425 & 5.144 \\
\hline L11 & 0.01962 & 12.030 & 0.004273 & 6.524 \\
\hline L12 & 0.02504 & 14.817 & 0.005263 & 6.760 \\
\hline L13 & 0.01776 & 13.290 & 0.004721 & 5.345 \\
\hline L14 & 0.01769 & 17.358 & 0.006166 & 4.076 \\
\hline L15 & 0.01785 & 16.719 & 0.005939 & 4.271 \\
\hline L16 & 0.01754 & 16.130 & 0.005730 & 4.349 \\
\hline L17 & 0.01674 & 16.441 & 0.005840 & 4.074 \\
\hline L18 & 0.01700 & 16.993 & 0.006036 & 4.002 \\
\hline G1 & 0.02268 & 9.330 & 0.003314 & 9.723 \\
\hline G2 & 0.03582 & 19.707 & 0.007000 & 7.270 \\
\hline G3 & 0.04374 & 24.236 & 0.008609 & 7.219 \\
\hline G4 & 0.04097 & 22.473 & 0.007982 & 7.292 \\
\hline N1 & 0.03810 & 32.501 & 0.011545 & 4.689 \\
\hline $\mathrm{N} 2$ & 0.03466 & 25.529 & 0.009068 & 5.431 \\
\hline N3 & 0.01443 & 7.310 & 0.002597 & 7.897 \\
\hline N4 & 0.01908 & 8.361 & 0.002970 & 9.128 \\
\hline N5 & 0.02636 & 12.241 & 0.004348 & 8.616 \\
\hline N6 & 0.01596 & 11.522 & 0.004093 & 5.539 \\
\hline N7 & 0.01463 & 12.708 & 0.004514 & 4.605 \\
\hline N8 & 0.02181 & 23.903 & 0.008491 & 3.649 \\
\hline N9 & 0.02408 & 27.001 & 0.009591 & 3.567 \\
\hline N10 & 0.00195 & 1.645 & 0.000584 & 4.749 \\
\hline N11 & 0.00272 & 2.760 & 0.000981 & 3.947 \\
\hline N12 & 0.00528 & 4.770 & 0.001694 & 4.424 \\
\hline N13 & 0.00327 & 1.969 & 0.000699 & 6.638 \\
\hline N14 & 0.00520 & 3.615 & 0.001284 & 5.757 \\
\hline N15 & 0.00414 & 2.464 & 0.000875 & 6.718 \\
\hline N16 & 0.01894 & 20.172 & 0.007165 & 3.755 \\
\hline N17 & 0.00548 & 2.755 & 0.000979 & 7.951 \\
\hline WL1 & 0.03652 & 30.101 & 0.010692 & 4.853 \\
\hline WL2 & 0.02327 & 20.838 & 0.007402 & 4.467 \\
\hline WL3 & 0.01267 & 10.750 & 0.003818 & 4.716 \\
\hline WL4 & 0.02802 & 22.616 & 0.008033 & 4.956 \\
\hline WL5 & 0.02652 & 24.178 & 0.008588 & 4.387 \\
\hline
\end{tabular}


TABLE 2: Continued.

\begin{tabular}{lcccc}
\hline Number & $\begin{array}{c}\text { Total pore } \\
\text { volume } \\
\left(\mathrm{cm}^{3} / \mathrm{g}\right)\end{array}$ & $\begin{array}{c}\text { Specific } \\
\text { surface area } \\
\left(\mathrm{m}^{2} / \mathrm{g}\right)\end{array}$ & $\begin{array}{c}\text { Monolayer } \\
\text { volume } \\
\left(\mathrm{cm}^{3} / \mathrm{g}\right)^{\mathrm{a}}\end{array}$ & $\begin{array}{c}\text { Average } \\
\text { pore size } \\
(\mathrm{nm})^{\mathrm{b}}\end{array}$ \\
\hline WL6 & 0.02577 & 23.487 & 0.008343 & 4.389 \\
WL7 & 0.02420 & 20.779 & 0.007381 & 4.658 \\
WL8 & 0.01992 & 16.694 & 0.005930 & 4.773 \\
WL9 & 0.02391 & 22.12 & 0.007857 & 4.324 \\
WL10 & 0.02433 & 22.321 & 0.007929 & 4.360 \\
WL11 & 0.02993 & 17.34 & 0.006159 & 6.904 \\
WL12 & 0.02194 & 19.528 & 0.006936 & 4.494 \\
WL13 & 0.02092 & 18.65 & 0.006625 & 4.488 \\
WL14 & 0.02174 & 17.027 & 0.006048 & 5.106 \\
\hline
\end{tabular}

${ }^{\mathrm{a}}$ The monolayer volume is calculated by BET method [25]. ${ }^{\mathrm{b}}$ Average pore size $=4 *$ Total pore volume $/$ specific surface area.

of Pure and Applied Chemistry (IUPAC) classification [29]. The marine shales in southern China are similar to the North American shales in terms of specific surface area and total pore volume $[6,30,31]$.

The permeability and Langmuir volume of marine shale samples are illustrated in Table 3. From Table 3, the pulsedecay permeability values of marine shale samples are commonly less than $1 \mu \mathrm{D}$. Permeability values of these shale samples were lower than the Besa River, Muskwa, and Fort Simpson shale from Northeastern British Columbia [32]. And permeability values of these shale samples were bigger than the Barnett shale from Fort Worth Basin [33], which may be related to types of samples for measuring. Type of marine shale samples in southern China for measuring permeability was core plug, whereas type of Barnett shale samples was crushed sample. In addition, we observe that the difference of Langmuir volume of shale samples from the different references was great, which may be related to the experiment conditions of shale samples.

3.2. $\mathrm{N}_{2}$ Adsorption-Desorption Isotherms. The isotherms for the low-pressure $\mathrm{N}_{2}$ adsorption analysis of some shale samples are listed in Figure 1. The isotherm of each shale sample has difference in shape, while the isotherm of all shale samples belongs to type IV isotherms according to the BDDT classification [34]. The adsorption branch and the desorption branch of $\mathrm{N}_{2}$ adsorption-desorption isotherm at higher relative pressure (more than 0.45 ) exist separation because of capillary condensation, resulting in a hysteresis loop [35], which mean that shale samples contain mesopore [36]. Meanwhile, from the figure, we can note that the absence of total closure of the hysteresis loop of shale samples L2 and L7 was interpreted as being due to the effect of swelling [35].

The shape of the hysteresis loop can be used to understand the pore shape of shale [36]. According to the hysteresis loop shape of $\mathrm{N}_{2}$ adsorption-desorption isotherms, the shale samples can be divided into two groups: group A (sample L2, sample L7, and sample N2) and group B (sample N5, sample WL4, and sample WL11) (Figure 1 and Table 4). The adsorption-desorption isotherms of some shale samples
TABle 3: Permeability and methane adsorption results for some shale samples.

\begin{tabular}{|c|c|c|c|}
\hline Number & $\begin{array}{c}\text { Permeability } \\
(\mu \mathrm{D})\end{array}$ & $\begin{array}{l}\text { Langmuir volume } \\
\left(\mathrm{cm}^{3} / \mathrm{g}\right)\end{array}$ & Source \\
\hline L1 & - & - & \multirow{6}{*}[1]{} \\
\hline L2 & - & 0.52 & \\
\hline L3 & - & 0.58 & \\
\hline $\mathrm{L} 4$ & - & 0.52 & \\
\hline L5 & - & 0.43 & \\
\hline L6 & - & 0.51 & \\
\hline L7 & 0.6999 & - & \multirow{7}{*}{ In this study } \\
\hline L8 & 0.6039 & - & \\
\hline L9 & 0.7431 & - & \\
\hline L10 & 0.4142 & - & \\
\hline L11 & 0.3502 & - & \\
\hline L12 & 0.3782 & - & \\
\hline $\mathrm{L} 13$ & 0.4264 & - & \\
\hline N1 & 0.40 & 13.44 & \multirow{2}{*}[7]{} \\
\hline $\mathrm{N} 2$ & 0.32 & 12.10 & \\
\hline N3 & 0.67 & 9.63 & \multirow{3}{*}[7]{} \\
\hline N4 & 0.70 & 9.41 & \\
\hline N5 & 0.55 & 4.03 & \\
\hline N6 & - & 3.34 & \multirow{12}{*}[10]{} \\
\hline N7 & - & 2.43 & \\
\hline N8 & - & 4.36 & \\
\hline N9 & - & 5.04 & \\
\hline N10 & - & 2.01 & \\
\hline N11 & - & 1.83 & \\
\hline $\mathrm{N} 12$ & - & 2.62 & \\
\hline N13 & - & 1.13 & \\
\hline N14 & - & 1.24 & \\
\hline N15 & - & 1.18 & \\
\hline N16 & - & 4.69 & \\
\hline N17 & - & 2.20 & \\
\hline
\end{tabular}

belong to group $\mathrm{A}$, which are reversible at low relative pressure, but, at higher relative pressure (more than 0.45), the desorption branches of the isotherms exist inflection point. And type of the hysteresis loops may be considered as type $\mathrm{H} 2$ according to the IUPAC classification [36]. Type $\mathrm{H} 2$ hysteresis loop is usually observed in open pores, which contain mainly inkbottle-shaped pores and a small amount of parallel-plate pores or cylindrical pores $[7,22,36]$. In contrast, at higher relative pressure (more than 0.45), the desorption branches of the isotherms of some shale samples belonging to group B do not exist inflection point. According to the IUPAC classification [36], type of the hysteresis loops may be classified as type $\mathrm{H} 3$, which is usually associated with slit-shaped pores $[7,22,36]$.

3.3. Fractal Dimension from $\mathrm{N}_{2}$ Adsorption Data. According to the fractal $\mathrm{FHH}$ model, the plots of $\ln (V)$ versus $\ln \left(\ln \left(p_{0} / p\right)\right)$ from $\mathrm{N}_{2}$ adsorption data are illustrated in Figure 2. From Figure 2, we observe that there are two distinct straight line segments at the whole relative pressure range, 

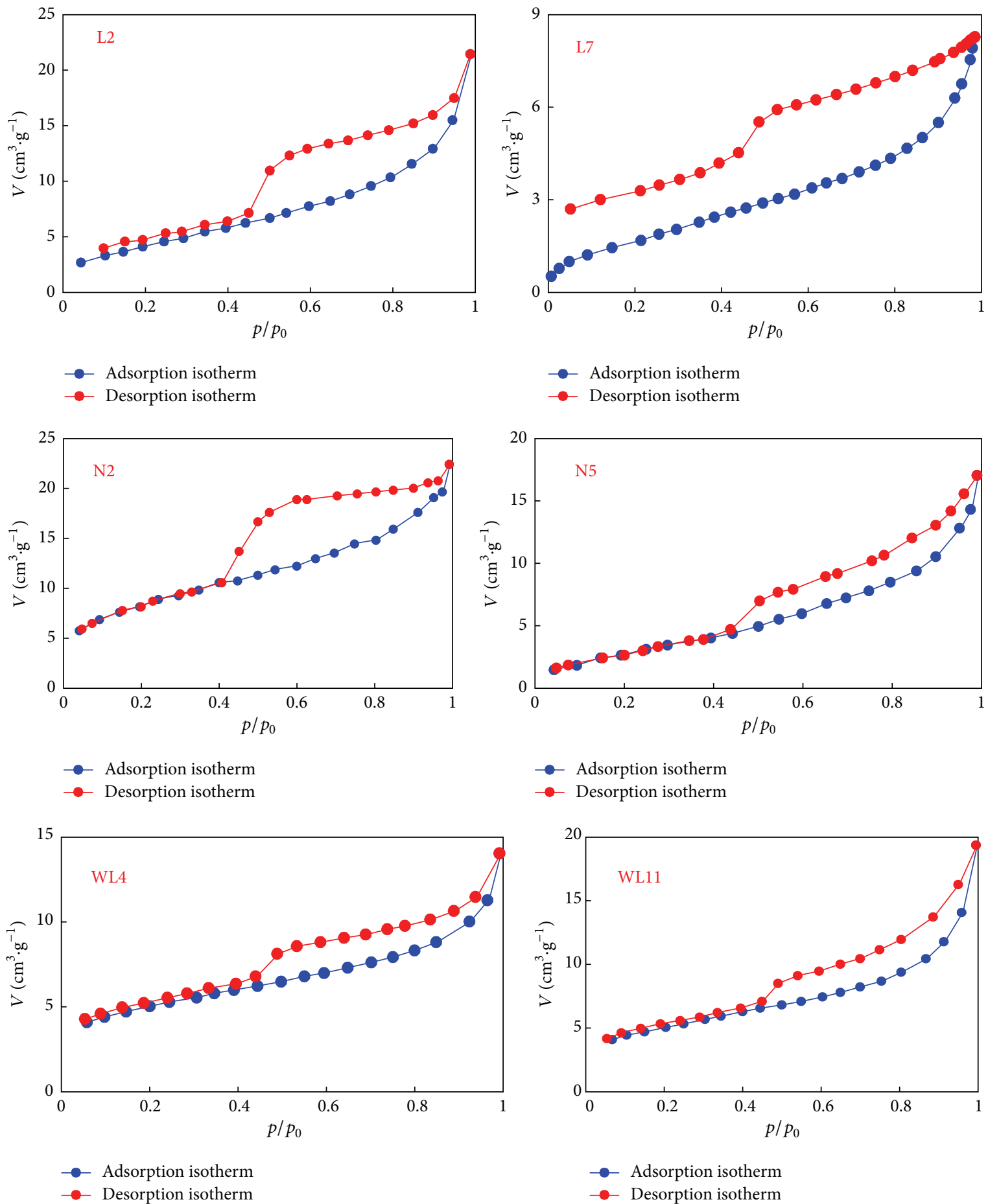

$\rightarrow$ Adsorption isotherm
$\rightarrow$ Desorption isotherm

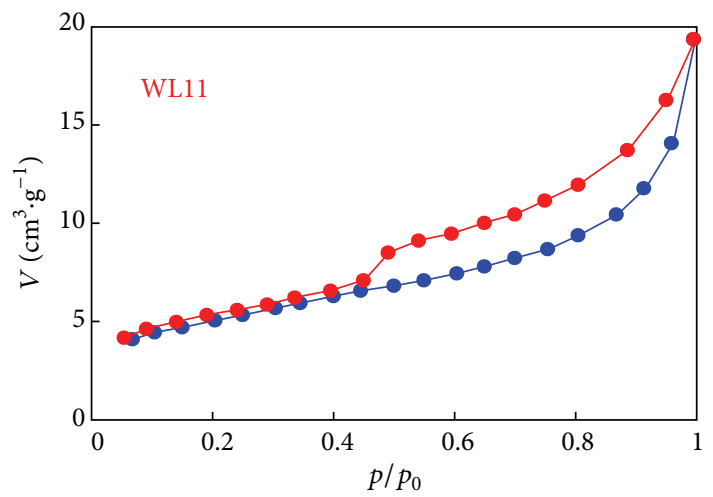

- Adsorption isotherm

- Desorption isotherm

FIGURE 1: Low-pressure $\mathrm{N}_{2}$ adsorption-desorption isotherms of some shale samples.

and the liners can obtain different slops with piecewise fitting. A demarcation point between straight line segment at low relative pressure range and straight line segment at high relative pressure range can be gained, and the pores would be divided into small pores and large pores, respectively. Meanwhile, both of them show good fitting, suggesting that the fractal characteristics at the two intervals are different, and the fractal dimensions $D_{1}$ and $D_{2}$ are calculated from the two linear segments (Table 4). From Table 4, we observe that all correlation coefficients are more than 0.94 , suggesting that there are the fractal characteristics for marine shales in southern China. Values of fractal dimension $D_{1}$ range from 2.0918 to 2.718 with a mean value of 2.4762 , and values of fractal dimension $D_{2}$ range from 2.5842 to 2.9399 with a mean value of 2.8015 , indicating that there are irregular pore surface and sophisticated pore structure in shales. 

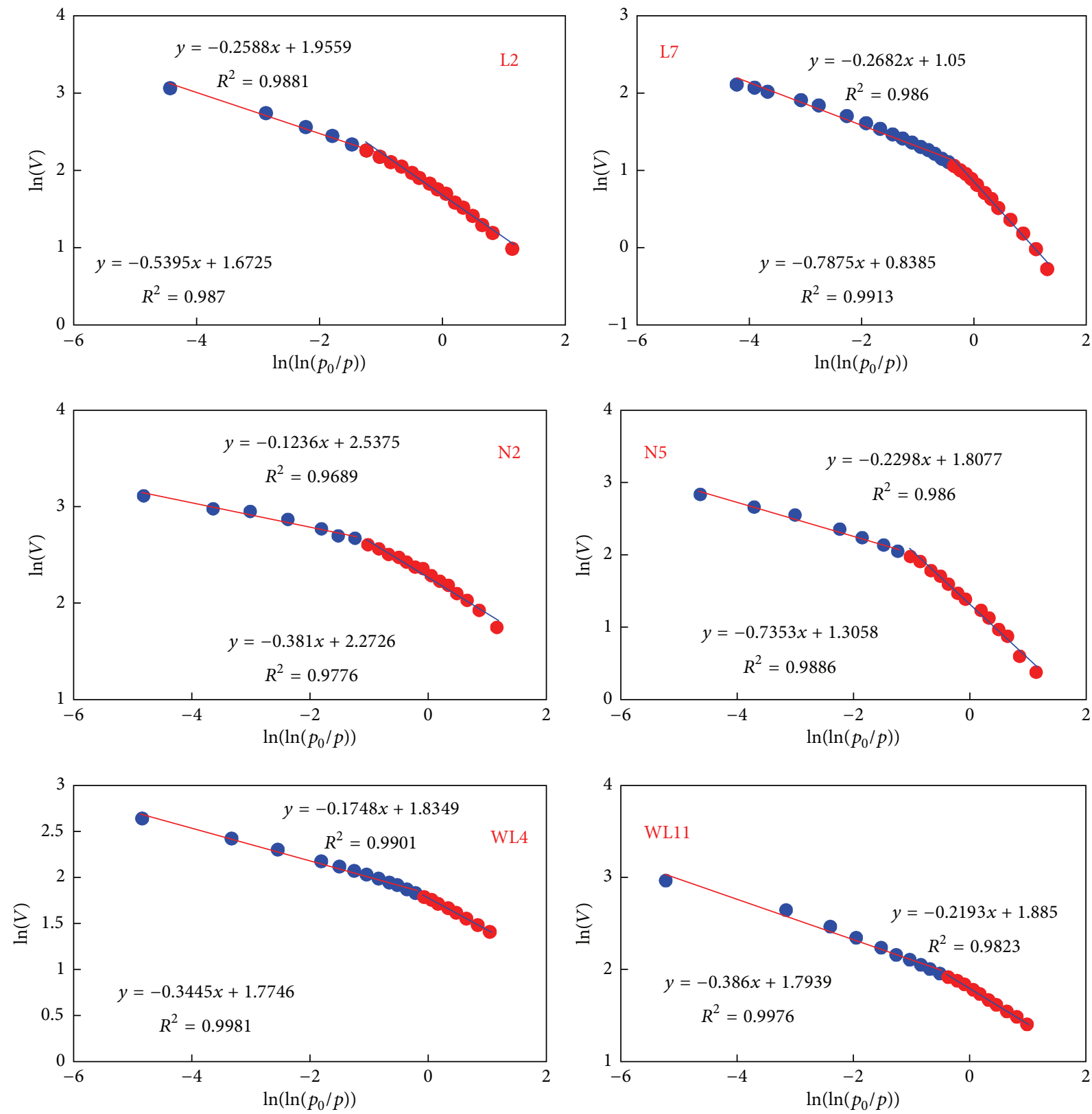

Figure 2: Plots of $\ln (V)$ versus $\ln \left(\ln \left(p_{0} / p\right)\right)$ reconstructed from the $\mathrm{N}_{2}$ adsorption data of some shale samples.

The value of fractal dimension $D_{1}$ is generally less than fractal dimension $D_{2}$, indicating that the complexity of pore structure of large pore is more than that of small pore. This conclusion is consistent with previous work on coals and sandstones [21, 22]. In addition, Figure 3 reports that no clear correlation between fractal dimension $D_{1}$ and fractal dimension $D_{2}$ is observed, suggesting that they represent two different fractal dimensions of marine shales in southern China. This conclusion shows that the marine shales have double fractal characteristics, which is in disagreement with the previous study on the continental shales [16]. This is may be related to the continental shales that included a small amount of micropores.

From Table 4, we also observe that the fractal dimension $D_{1}$ ranges from 2.0918 to 2.693 with an average of 2.4339 and the fractal dimension $D_{2}$ ranges from 2.713 to 2.9399 with an average of 2.8144 in group $\mathrm{A}$ and the fractal dimension $D_{1}$ ranges from 2.2438 to 2.718 with an average of 2.5654 and the fractal dimension $D_{2}$ ranges from 2.5842 to 2.8692 with an average of 2.7762 in group B. Comparisons of fractal dimension $D_{1}$ and fractal dimension $D_{2}$ of shale in groups $\mathrm{A}$ and $B$ are shown in Figure 4. Comparing samples in groups $\mathrm{A}$ and $\mathrm{B}$ (Figure 4), the minimum, average, and maximum of fractal dimension $D_{1}$ in group $\mathrm{A}$ are smaller than those in group $B$; the minimum, average, and maximum of fractal dimension $D_{2}$ in group $\mathrm{A}$ are greater than those in group $\mathrm{B}$. The hysteresis loop shape of shale samples in group A can be considered as type $\mathrm{H} 2$, which occurs mainly in inkbottleshaped pores, whereas the hysteresis loop shape of shale samples in group B can be considered as type $\mathrm{H} 3$, which 
TABLE 4: Fractal dimensions derived from fractal FHH model.

\begin{tabular}{|c|c|c|c|c|c|}
\hline Number & $D_{1}$ & $\begin{array}{c}\text { Coefficient } \\
\left(R^{2}\right)\end{array}$ & $D_{2}$ & $\begin{array}{c}\text { Coefficient } \\
\left(R^{2}\right)\end{array}$ & Group $^{\mathrm{a}}$ \\
\hline $\mathrm{L} 1$ & 2.6896 & 0.9981 & 2.812 & 0.9788 & A \\
\hline $\mathrm{L} 2$ & 2.4605 & 0.987 & 2.7412 & 0.9881 & A \\
\hline L3 & 2.6734 & 0.9982 & 2.8218 & 0.9899 & B \\
\hline $\mathrm{L} 4$ & 2.58 & 0.9836 & 2.8033 & 0.9978 & B \\
\hline L5 & 2.2438 & 0.9944 & 2.6854 & 0.9917 & B \\
\hline L6 & 2.6261 & 0.9918 & 2.7729 & 0.9956 & B \\
\hline L7 & 2.2125 & 0.9913 & 2.7318 & 0.986 & A \\
\hline L8 & 2.0918 & 0.9959 & 2.7248 & 0.979 & A \\
\hline L9 & 2.1558 & 0.9857 & 2.7467 & 0.9724 & A \\
\hline L10 & 2.2654 & 0.9785 & 2.8091 & 0.971 & A \\
\hline L11 & 2.2039 & 0.9416 & 2.8364 & 0.9718 & A \\
\hline L12 & 2.2978 & 0.9134 & 2.8395 & 0.9785 & A \\
\hline L13 & 2.1908 & 0.9254 & 2.8044 & 0.9795 & A \\
\hline L14 & 2.5074 & 0.9905 & 2.8355 & 0.9649 & A \\
\hline L15 & 2.5324 & 0.991 & 2.8303 & 0.9753 & A \\
\hline L16 & 2.4979 & 0.958 & 2.8541 & 0.9471 & A \\
\hline L17 & 2.4588 & 0.9915 & 2.8356 & 0.9544 & A \\
\hline L18 & 2.4784 & 0.9838 & 2.8429 & 0.9789 & A \\
\hline G1 & 2.3986 & 0.9815 & 2.6615 & 0.9906 & B \\
\hline G2 & 2.621 & 0.9841 & 2.6746 & 0.9901 & B \\
\hline G3 & 2.718 & 0.9796 & 2.8109 & 0.979 & B \\
\hline G4 & 2.708 & 0.987 & 2.7977 & 0.9902 & B \\
\hline N1 & 2.6687 & 0.9652 & 2.9399 & 0.9807 & A \\
\hline $\mathrm{N} 2$ & 2.619 & 0.9769 & 2.8764 & 0.9689 & A \\
\hline N3 & 2.4077 & 0.9865 & 2.8075 & 0.9563 & A \\
\hline N4 & 2.4372 & 0.9565 & 2.7718 & 0.9471 & A \\
\hline N5 & 2.2647 & 0.9887 & 2.7702 & 0.986 & B \\
\hline N6 & 2.6032 & 0.9878 & 2.808 & 0.9932 & A \\
\hline N7 & 2.5529 & 0.9893 & 2.8402 & 0.9745 & A \\
\hline N8 & 2.6577 & 0.9879 & 2.8615 & 0.9671 & A \\
\hline N9 & 2.6515 & 0.9885 & 2.8654 & 0.9575 & A \\
\hline N10 & 2.2483 & 0.9771 & 2.7687 & 0.9719 & A \\
\hline N11 & 2.3956 & 0.9757 & 2.8015 & 0.993 & A \\
\hline N12 & 2.4447 & 0.9939 & 2.7269 & 0.9972 & A \\
\hline N13 & 2.2019 & 0.9783 & 2.713 & 0.9878 & A \\
\hline N14 & 2.2416 & 0.9992 & 2.7849 & 0.9949 & A \\
\hline N15 & 2.2559 & 0.9904 & 2.8384 & 0.9935 & A \\
\hline N16 & 2.5229 & 0.9747 & 2.8901 & 0.9649 & A \\
\hline N17 & 2.2298 & 0.9935 & 2.5842 & 0.9823 & B \\
\hline WL1 & 2.693 & 0.9954 & 2.8513 & 0.9622 & A \\
\hline WL2 & 2.6797 & 0.9968 & 2.8336 & 0.9926 & A \\
\hline WL3 & 2.2749 & 0.9863 & 2.8044 & 0.9786 & A \\
\hline WL4 & 2.6555 & 0.9981 & 2.8252 & 0.9901 & A \\
\hline WL5 & 2.6358 & 0.9859 & 2.8259 & 0.9453 & A \\
\hline WL6 & 2.6267 & 0.996 & 2.8533 & 0.9632 & B \\
\hline WL7 & 2.6055 & 0.9962 & 2.7681 & 0.9902 & B \\
\hline
\end{tabular}

TABle 4: Continued.

\begin{tabular}{lccccc}
\hline Number & $D_{1}$ & $\begin{array}{c}\text { Coefficient } \\
\left(R^{2}\right)\end{array}$ & $D_{2}$ & $\begin{array}{c}\text { Coefficient } \\
\left(R^{2}\right)\end{array}$ & Group $^{\text {a }}$ \\
\hline WL8 & 2.4996 & 0.9962 & 2.8259 & 0.9902 & $\mathrm{~A}$ \\
WL9 & 2.5891 & 0.9864 & 2.8062 & 0.9821 & $\mathrm{~B}$ \\
WL10 & 2.6265 & 0.9972 & 2.8418 & 0.975 & $\mathrm{~B}$ \\
WL11 & 2.614 & 0.9976 & 2.7807 & 0.9823 & $\mathrm{~B}$ \\
WL12 & 2.5759 & 0.9652 & 2.8395 & 0.958 & $\mathrm{~B}$ \\
WL13 & 2.5519 & 0.9981 & 2.8698 & 0.9565 & $\mathrm{~B}$ \\
WL14 & 2.5966 & 0.9858 & 2.8316 & 0.9683 & $\mathrm{~B}$ \\
\hline
\end{tabular}

${ }^{\mathrm{a}}$ Types of adsorption-desorption isotherms are divided into group $\mathrm{A}$ and group B.

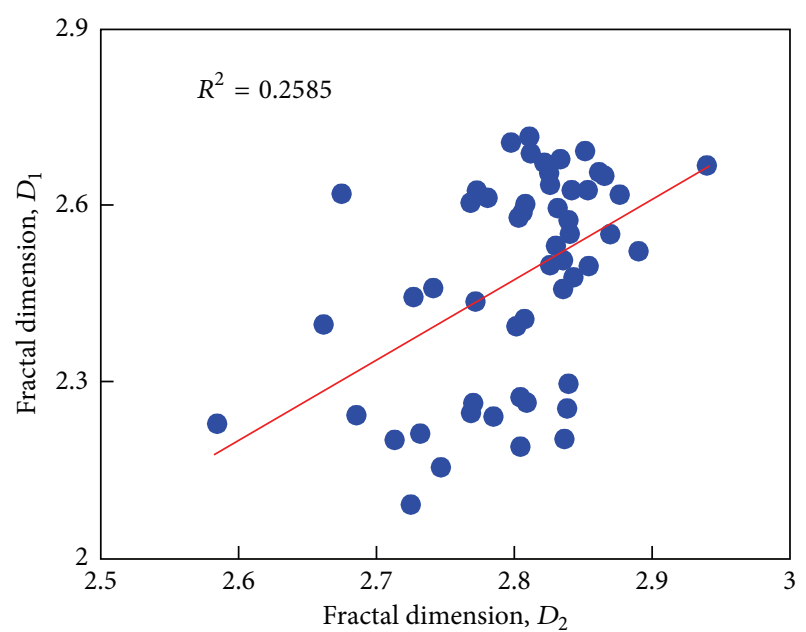

FIGURE 3: Relationship between fractal dimension $D_{1}$ and fractal dimension $\mathrm{D}_{2}$.

is usually associated with slit-shaped pores. And the pore structure of shale samples in group A is more complicated than that in group B. Therefore, the fractal dimension $D_{2}$ at higher relative pressure may be used to characterize the complexity of pore structure in shales, which is in agreement with previous study on coals [22], suggesting that the fractal dimension $\mathrm{D}_{2}$ at higher relative pressure represents the complexity of pore structure in coals.

3.4. Relationships between Fractal Dimension and Pore Structure Parameters. The relationships between fractal dimension and pore structure parameters (specific surface area, total pore volume, and average pore size) are listed in Figure 5. From Figure 5, we observe that there is good positive correlation between the fractal dimension $D_{1}$ and specific surface area $\left(R^{2}=0.6584\right.$ in Figure 5(a) $)$ and moderate positive correlation between the fractal dimension $D_{1}$ and total pore volume $\left(R^{2}=0.472\right.$ in Figure $\left.5(\mathrm{~b})\right)$. However, the fractal dimension $\mathrm{D}_{2}$ has a poor positive relationship with specific surface area $\left(R^{2}=0.3622\right.$ in Figure $\left.5(a)\right)$ and no obvious relationship with total pore volume $\left(R^{2}=0.0756\right.$ in Figure 5(b)). The good or moderate positive relationships indicate that shale with a higher total pore volume or specific 


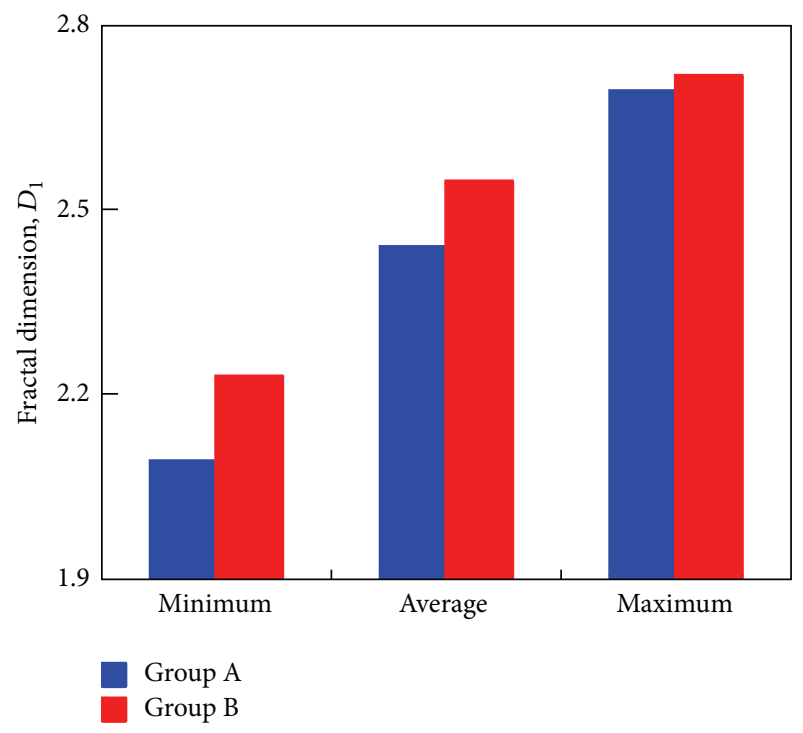

(a)

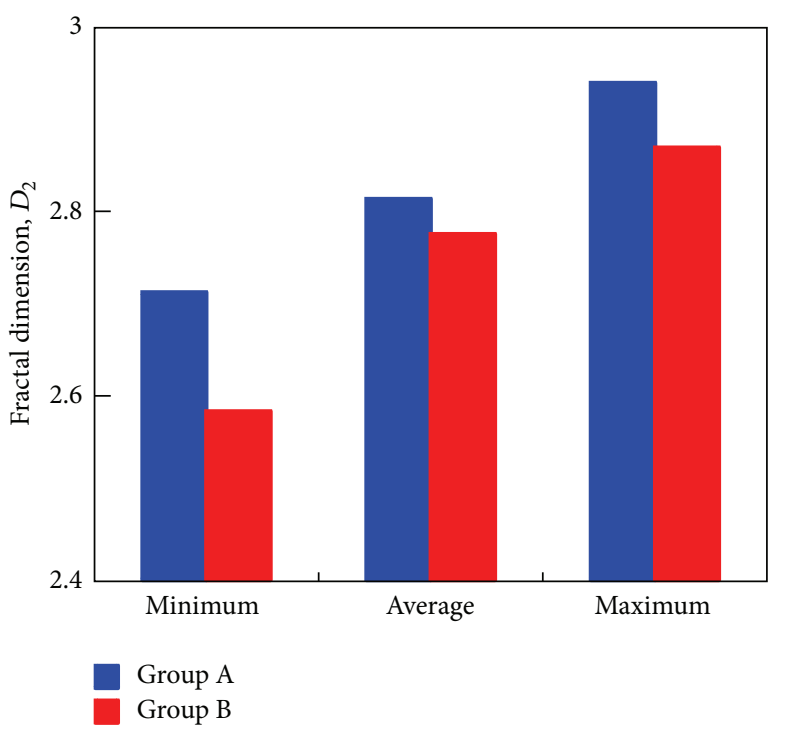

(b)

Figure 4: Comparison of fractal dimension $D_{1}$ and fractal dimension $D_{2}$ of shale in groups $\mathrm{A}$ and $\mathrm{B}$.

surface area may have a greater fractal dimension $D_{1}$. This finding is in agreement with previous research on coals [22]. Meanwhile, we also observe that there is a good positive relationship between fractal dimension $D_{1}$ and monolayer volume $\left(R^{2}=0.6584\right.$ in Figure 5(c)), whereas a poor positive relationship between fractal dimension $D_{2}$ and monolayer volume $\left(R^{2}=0.3622\right.$ in Figure 5(c)), indicating that shale with a higher monolayer volume would have more roughness pore surface and higher fractal dimension $D_{1}$. In addition, the relationship between fractal dimension and average pore size is shown in Figure 5(d). From this figure, the fractal dimension $D_{1}$ has a moderate negative correlation with the average pore size $\left(R^{2}=0.4321\right.$ in Figure $\left.5(\mathrm{~d})\right)$, while the fractal dimension $D_{2}$ has a poor negative correlation with the average pore size $\left(R^{2}=0.1465\right.$ in Figure $\left.5(\mathrm{~d})\right)$, suggesting that the fractal dimension $D_{2}$ decreases with increasing average pore size. Shale with smaller average pore size would have more micropores [7] and higher fractal dimension $D_{2}$, reflecting more complicated pore structure in shale.

Comparing the relationships in Figures 3-5, the fractal dimension $D_{1}$ at low relative pressure may reflect the surface fractal dimension, which may be used to characterize the roughness of pore surface of shale. However, the fractal dimension $\mathrm{D}_{2}$ at higher relative pressure may represent the pore structure fractal dimension, which may be used to describe the complexity of pore structure of shale. From Table 4 , we observe that the fractal dimension $D_{1}$ has large variable ranges, indicating that the surface of some pores in shale is regularity, whereas the surface of some pores is toughness. With the fractal dimension $D_{1}$ increasing, the pore surface in shale transforms gradually from smoothness to toughness, which suggests that the roughness of pore surface in shale exists difference, and the interaction potential energy between gas and soil surface shows uneven distribution, resulting in gas adsorption sites for gas in shale being inhomogeneous. Meanwhile, the fractal dimension $D_{2}$ has little variable ranges, indicating that the discrepancies among fractal characteristic of pore structure of each shale sample are relatively low. A higher fractal dimension $D_{2}$ indicates that a shale sample has a more irregular pore structure.

\subsection{Relationships between Fractal Dimension and Adsorption} Capacity and Flow Capacity. The fractal dimension $D_{1}$ and fractal dimension $\mathrm{D}_{2}$ represent the two different types of fractal characteristics of shale, which are pore surface fractal characteristics and pore structure fractal characteristics, respectively. Shale with a higher fractal dimension $D_{1}$ has a more rough pore surface, whereas shale with a higher fractal dimension $D_{2}$ has a more complicated pore structure. Relationships between fractal dimension and Langmuir volume of shale samples are shown in Figure 6. From this figure, there are significant positive correlations between fractal dimension $D_{1}$ and Langmuir volume from different literatures, which means that the adsorption capacity of shale increases with increasing fractal dimension $D_{1}$, whereas fractal dimension $D_{2}$ has different relationships with Langmuir volume from different literatures. Therefore, the fractal dimension $D_{1}$ has greater influence on adsorption capacity of shale than the fractal dimension $D_{2}$. This finding is in agreement with results from previous work on coals [22]. Shale with a higher fractal dimension $D_{1}$ has a more irregular pore surface that can provide more adsorption sites and the interface force between gas and the shale surface is greater, which would be beneficial to increase the adsorption amount of gas, leading to higher adsorption capacity of shale.

However, Yao et al. [19] and Cai et al. [20] suggested that the pore structure in coal had great effects on gas transport and coal with higher fractal dimension had less flow capacity. Chen et al. [21] studied the relationship between pore structure fractal dimension and permeability of sandstone and found that there was negative correlation 


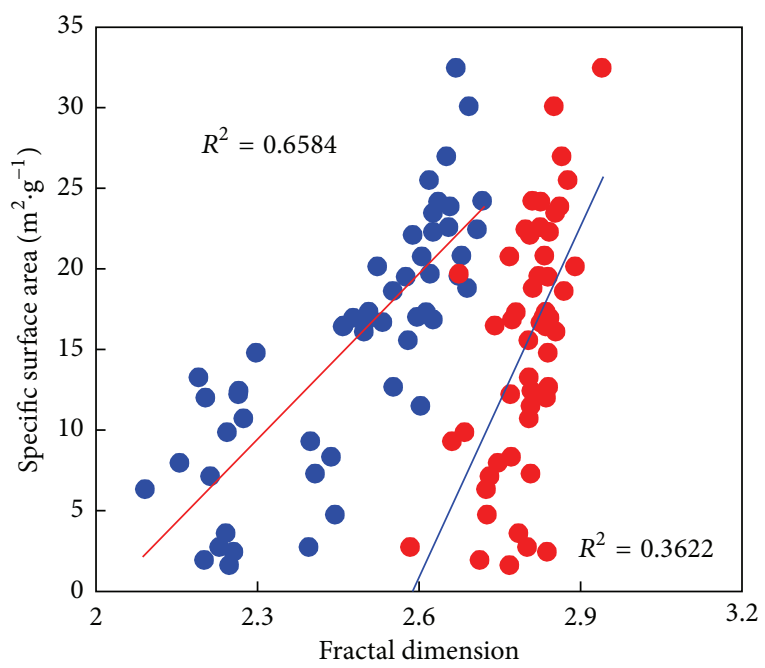

- $D_{1}$

- $D_{2}$

(a)

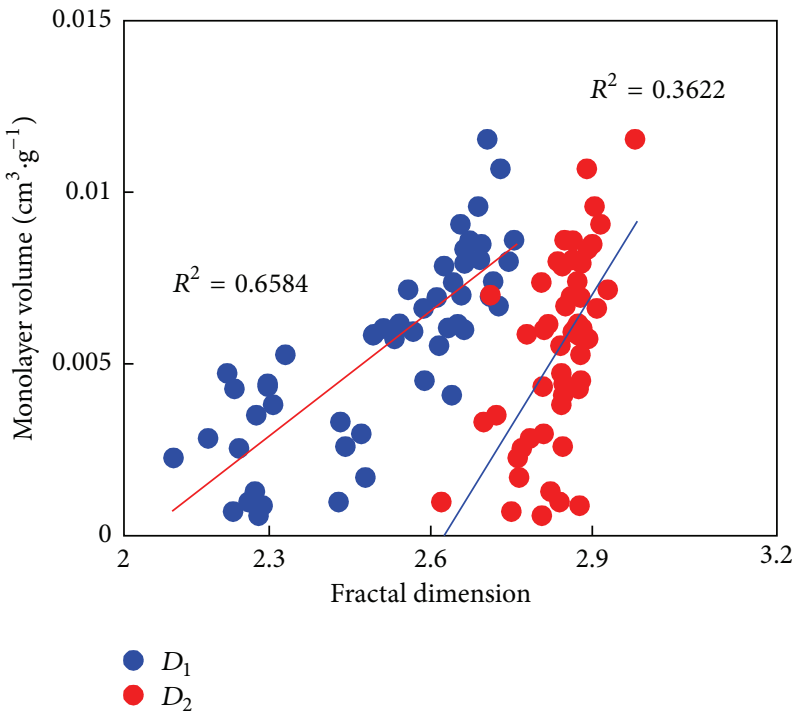

(c)

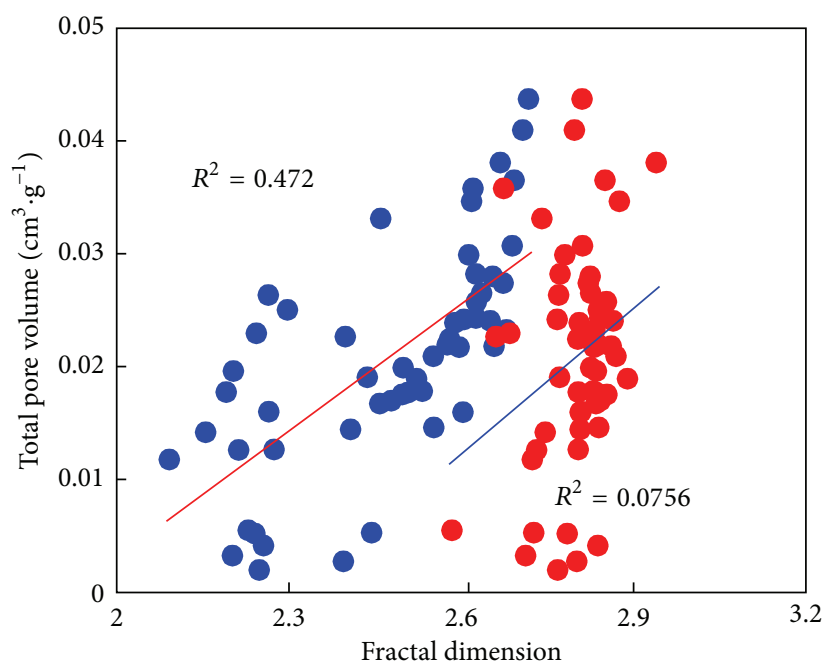

- $D_{1}$

- $\mathrm{D}_{2}$

(b)

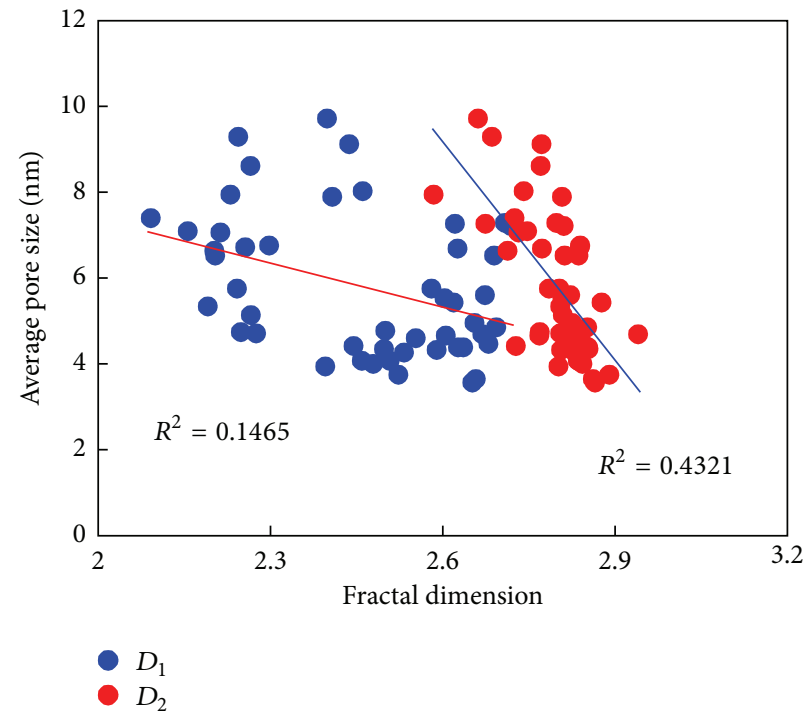

(d)

Figure 5: Relationships between fractal dimension and specific surface area (a), total pore volume (b), monolayer volume (c), and average pore size $(\mathrm{d})$.

between pore structure fractal dimension and permeability, which mean that sandstone with a higher pore structure fractal dimension has more complex pore structure, resulting in lower permeability. Figure 7 reports relationship between fractal dimension and permeability of shale samples. There is a good-moderate negative relationship between fractal dimension $D_{1}$ and permeability $\left(R^{2}=0.5635\right.$ in Figure 7), and the fractal dimension $D_{2}$ has a poor negative correlation with permeability $\left(R^{2}=0.1109\right.$ in Figure 7$)$. This finding suggests that the fractal dimension $D_{2}$ has greater influence on flow capacity of shale than the fractal dimension $D_{1}$. Therefore, shale with a higher fractal dimension $D_{2}$ has more complicated pore structure, resulting in lower permeability and flow capacity for gas, which makes gas adsorption, diffusion, and percolation much more difficult in shale.

Therefore, the two fractal dimensions have different impact on the development of shale gas reservoirs. Higher fractal dimension $D_{1}$ represents more roughness of pore surface of shale that offers more adsorption sites, leading to higher adsorption capacity of shale. However, higher fractal dimension $\mathrm{D}_{2}$ represents more complicated pore structure, resulting in the decrease of permeability of shale, which makes gas adsorption, diffusion, and percolation become much more difficult. Comparing the influences of two fractal dimensions on the adsorption capacity and flow capacity, we consider higher surface fractal dimension $D_{1}$ and lower pore structure fractal dimension $D_{2}$ in shale as having 


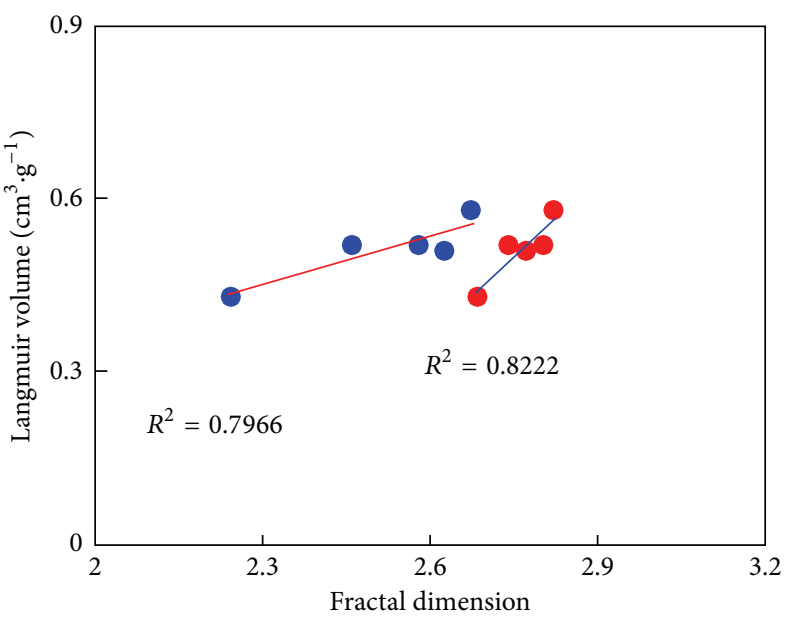

$D_{1}$

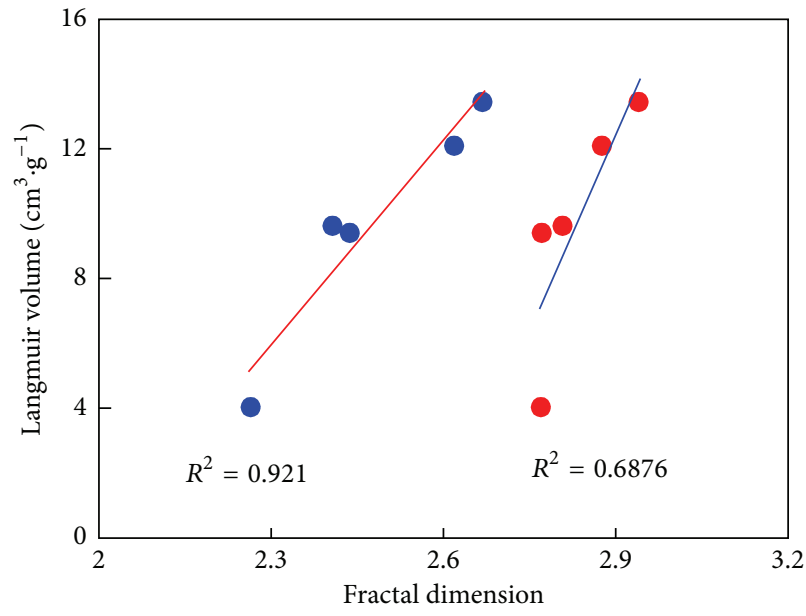

$D_{1}$

- $D_{2}$

(a)

(b)

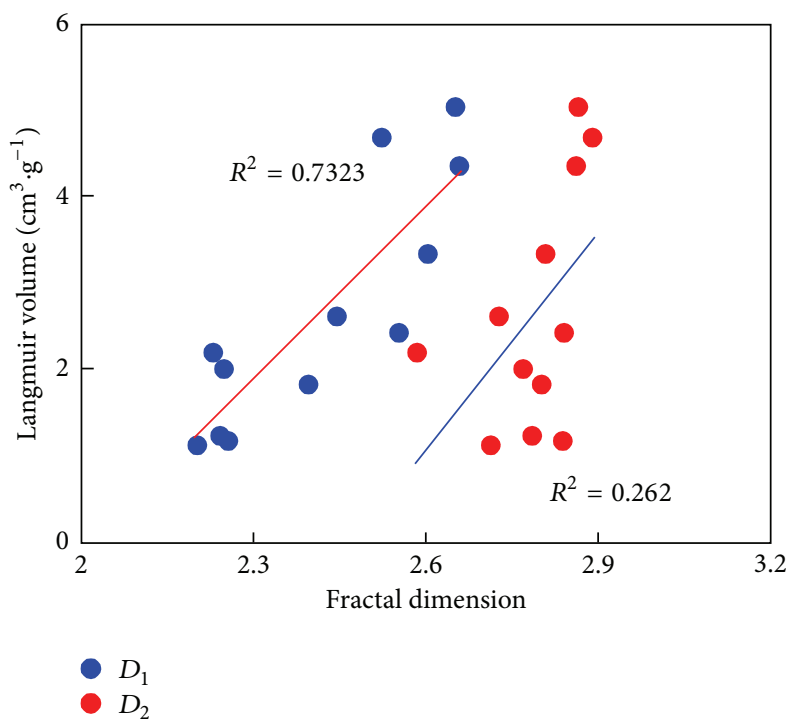

(c)

Figure 6: Relationships between fractal dimension and Langmuir volume (data in (a) from [1]; data in (b) from [7]; data in (c) from [10]).

higher adsorption capacity for gas and flow capacity for gas, which has an important significance in the development of shale gas reservoirs. In conclusion, shale with a greater fractal dimension $D_{1}$ has stronger adsorption capacity and should use stimulation treatment forming fracture networks to increase the flow capability for gas (decrease the fractal dimension $D_{2}$ ), which lead to accelerating velocity of gas desorption and increasing the gas production.

\section{Conclusions}

In this paper, the $\mathrm{FHH}$ fractal model has been applied to investigate the fractal characteristics of marine shales in southern China from nitrogen adsorption data. The relationships between pore structure parameters and fractal dimension have been investigated. Furthermore, the relationships between fractal dimension and adsorption capacity and flow capacity of shale are also discussed. The following conclusions can be made:

(1) The marine shales in southern China have two different types of fractal characteristics; the fractal dimension $D_{1}$ at low relative pressure represents the pore surface fractal characteristics and the fractal dimension $D_{2}$ at higher relative pressure describes the pore structure fractal characteristics.

(2) The fractal dimensions $D_{1}$ range from 2.0918 to 2.718 with a mean value of 2.4762 , and the fractal dimensions $D_{2}$ range from 2.5842 to 2.9399 with a mean value of 2.8015, indicating that there are irregular pore 


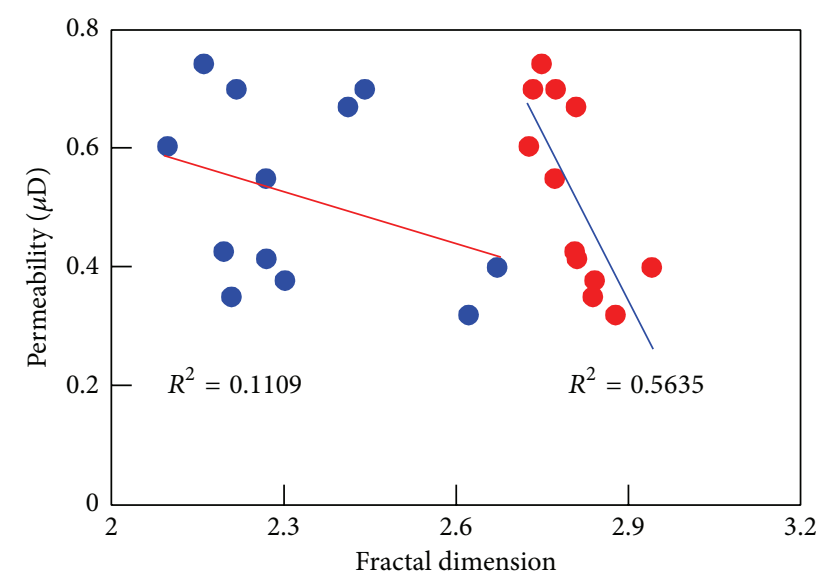

$D_{1}$

- $D_{2}$

FIGURE 7: Relationship between fractal dimension and permeability.

surface and sophisticated pore structure in marine shales.

(3) The fractal dimension $D_{1}$ has good or moderate positive relationships with specific surface area or total pore volume, whereas the fractal dimension $D_{2}$ shows moderate negative correlation with average pore size.

(4) The higher fractal dimension $D_{1}$ represents more roughness of pore surface of shale that offers more adsorption sites, leading to higher adsorption capacity for gas in shale. However, the higher fractal dimension $D_{2}$ represents higher heterogeneity of pore structure and more complicated pore structure, resulting in the lower flow capacity for gas in shale.

\section{Conflict of Interests}

The authors declare that there is no conflict of interests regarding the publication of this paper.

\section{Acknowledgments}

The authors would like to give sincere thanks for the continuous supply of funds. This research was supported by the United Fund Project of National Natural Science Foundation of China (Grant no. U1262209), the National Natural Science Foundation of China (NSFC) (Grant no. 51274172), and the Young scholars development fund of SWPU.

\section{References}

[1] S. Chen, Y. Zhu, H. Wang, H. Liu, W. Wei, and J. Fang, "Shale gas reservoir characterisation: a typical case in the southern Sichuan Basin of China," Energy, vol. 36, no. 11, pp. 6609-6616, 2011.

[2] R. Weijermars, G. Drijkoningen, T. J. Heimovaara, E. S. J. Rudolph, G. J. Weltje, and K. H. A. A. Wolf, "Unconventional gas research initiative for clean energy transition in Europe," Journal of Natural Gas Science and Engineering, vol. 3, no. 2, pp. 402-412, 2011.

[3] J. Li, M. Zheng, G. Zhang et al., "Potential and prospects of conventional and unconventional natural gas source in China," Acta Petrolei Sinica, vol. 33, supplement 1, pp. 89-98, 2012.

[4] U.S. Energy Information Administration (EIA), World Shale Gas Resources: An Initial Assessment of 14 Regions Outside the United States, [EB/OL], 2011, http://www.eia.gov/analysis/ studies/worldshalegas.

[5] H. Wang, Y. Liu, D. Dong, Q. Zhao, and D. Du, "Scientific issues on effective development of marine shale gas in Southern China," Petroleum Exploration and Development, vol. 40, no. 5, pp. 574-579, 2013.

[6] D. J. K. Ross and R. M. Bustin, "The importance of shale composition and pore structure upon gas storage potential of shale gas reservoirs," Marine and Petroleum Geology, vol. 26, no. 6, pp. 916-927, 2009.

[7] F. Yang, Z. Ning, and H. Liu, "Fractal characteristics of shales from a shale gas reservoir in the Sichuan Basin, China," Fuel, vol. 115, pp. 378-384, 2014.

[8] S. Chen, Y. Zhu, H. Wang, H. Liu, W. Wei, and J. Fang, "Structure characteristics and accumulation significance of nanopores in Longmaxi shale gas reservoir in the Southern Sichuan Basin," Journal of China Coal Society, vol. 24, no. 3, pp. 450-455, 2012.

[9] J. Li, B. Yu, J. Zhang, Y. Li, and J. Wu, "Reservoir characteristics and their influence factors of the Lower Cambrian dark shale in Northern Guizhou," Oil \& Gas Geology, vol. 33, no. 3, pp. 364374, 2012.

[10] S.-B. Han, J.-C. Zhang, C. Yang et al., "The characteristics of nanoscale pore and its gas storage capability in the Lower Cambrian shale of southeast Chongqing," Journal of the China Coal Society, vol. 38, no. 6, pp. 1038-1043, 2013.

[11] L. Pan, G. Chen, Q. Xu, and X. Xiao, "Pore structure characteristics of Permian organic-rich shale in Lower Yangtze area," Journal of the China Coal Society, vol. 38, no. 6, pp. 787-793, 2013.

[12] H. Tian, L. Pan, X. Xiao, R. W. T. Wilkins, Z. Meng, and B. Huang, "A preliminary study on the pore characterization of Lower Silurian black shales in the Chuandong Thrust Fold Belt, southwestern China using low pressure $\mathrm{N}_{2}$ adsorption and FESEM methods," Marine and Petroleum Geology, vol. 48, pp. 8-19, 2013.

[13] F. Yang, Z. Ning, C. Hu, B. Wang, K. Peng, and H. Liu, "Characterization of microscopic pore structures in shale reservoirs," Acta Petrolei Sinica, vol. 34, no. 2, pp. 301-311, 2013.

[14] F. Yang, Z.-F. Ning, D.-T. Kong, and H.-Q. Liu, "Pore structure of shale from high pressure mercury injection and nitrogen adsorption method," Natural Gas Geoscience, vol. 24, no. 3, pp. 450-455, 2013.

[15] X. Cao, B. Yu, X. Li, M. Sun, and L. Zhang, "Reservoir characteristics and evaluation on logging of the Lower Cambrian gas shale in southeast Chongqing: a case study of Well Yuke 1 and Well Youke 1," Acta Petrolei Sinica, vol. 35, no. 2, pp. 233-244, 2014.

[16] X. Liu, J. Xiong, and L. Liang, "Investigation of pore structure and fractal characteristics of organic-rich Yanchang formation shale in central China by nitrogen adsorption/desorption analysis," Journal of Natural Gas Science and Engineering, vol. 22, pp. 62-72, 2015.

[17] E. M. Schlueter, R. W. Zimmerman, P. A. Witherspoon, and N. G. W. Cook, "The fractal dimension of pores in sedimentary 
rocks and its influence on permeability," Engineering Geology, vol. 48, no. 3-4, pp. 199-215, 1997.

[18] A. P. Radlinski, M. A. Ioannidis, A. L. Hinde et al., "Angstromto-millimeter characterization of sedimentary rock microstructure," Journal of Colloid and Interface Science, vol. 274, no. 2, pp. 607-612, 2004.

[19] Y. Yao, D. Liu, D. Tang et al., "Fractal characterization of seepage-pores of coals from China: an investigation on permeability of coals," Computers and Geosciences, vol. 35, no. 6, pp. 1159-1166, 2009.

[20] Y. Cai, D. Liu, Z. Pan, Y. Yao, J. Li, and Y. Qiu, "Pore structure and its impact on $\mathrm{CH}_{4}$ adsorption capacity and flow capability of bituminous and subbituminous coals from Northeast China," Fuel, vol. 103, pp. 258-268, 2013.

[21] L. Chen, K. Tan, J. Liu, and S. Zeng, "Pore structure fractal features of the ore-bearing layer from a sandstone-type uranium deposit, Xinjiang," Acta Scientiarum Natralium Universitatis Sunyatseni, vol. 51, no. 6, pp. 139-144, 2012.

[22] Y. Yao, D. Liu, D. Tang, S. Tang, and W. Huang, "Fractal characterization of adsorption-pores of coals from North China: an investigation on $\mathrm{CH}_{4}$ adsorption capacity of coals," International Journal of Coal Geology, vol. 73, no. 1, pp. 27-42, 2008.

[23] C. Zou, D. Dong, S. Wang et al., "Geological characteristics and resource potential of shale gas in China," Petroleum Exploration and Development, vol. 37, no. 6, pp. 641-653, 2010.

[24] S. Wang, The Study of the Shale (Gas) Features in Upper Ordovician-Lower Silurian, Uplift in the Northern of Guizhou, Chengdu University of Technology, Chengdu, China, 2013.

[25] S. Brunauer, P. H. Emmett, and E. Teller, "Adsorption of gases in multimolecular layers," Journal of the American Chemical Society, vol. 60, no. 2, pp. 309-319, 1938.

[26] P. Pfeifer and D. Avnir, "Chemistry in noninteger dimensions between two and three. I. Fractal theory of heterogeneous surfaces," The Journal of Chemical Physics, vol. 79, no. 7, pp. 3369-3558, 1983.

[27] D. Avnir and M. Jaroniec, "An isotherm equation for adsorption on fractal surfaces of heterogeneous porous materials," Langmuir, vol. 5, no. 6, pp. 1412-1433, 1989.

[28] M. Jaroniec, "Evaluation of the fractal dimension from a single adsorption isotherm," Langmuir, vol. 11, no. 6, pp. 2316-2317, 1995.

[29] J. Rouquerol, D. Avnir, C. W. Fairbridge et al., "Recommendations for the characterization of porous solids," International Union of Pure and Applied Chemistry, vol. 66, no. 8, pp. 17391758, 1994.

[30] C. R. Clarkson, N. Solano, R. M. Bustin et al., "Pore structure characterization of North American shale gas reservoirs using USANS/SANS, gas adsorption, and mercury intrusion," Fuel, vol. 103, pp. 606-616, 2013.

[31] D. Strąpoć, M. Mastalerz, A. Schimmelmann, A. Drobniak, and N. R. Hasenmueller, "Geochemical constraints on the origin and volume of gas in the New Albany Shale (DevonianMississippian), eastern Illinois Basin," AAPG Bulletin, vol. 94, no. 11, pp. 1713-1740, 2010.

[32] D. J. K. Ross and R. M. Bustin, "Characterizing the shale gas resource potential of Devonian-Mississippian strata in the Western Canada sedimentary basin: application of an integrated formation evaluation," AAPG Bulletin, vol. 92, no. 1, pp. 87-125, 2008.
[33] F. P. Wang and R. M. Reed, "Pore networks and fluid flow in gas shales," in Proceedings of the SPE Annual Technical Conference and Exhibition, New Orleans, La, USA, October 2009.

[34] S. Brunauer, L. S. Deming, W. E. Deming, and E. Teller, "On a theory of the van der Waals adsorption of gases," Journal of The American Chemical Society, vol. 62, no. 7, pp. 1723-1732, 1940.

[35] S. J. Gregg and K. S. W. Sing, Adsorption, Surface Area, and Porosity, Academic Press, New York, NY, USA, 1982.

[36] K. S. W. Sing, D. H. Everett, R. A. W. Haul et al., "Reporting physisorption data for gas/solid systems with special reference to the determination of surface area and porosity," Pure and Applied Chemistry, vol. 57, no. 4, pp. 603-619, 1985. 

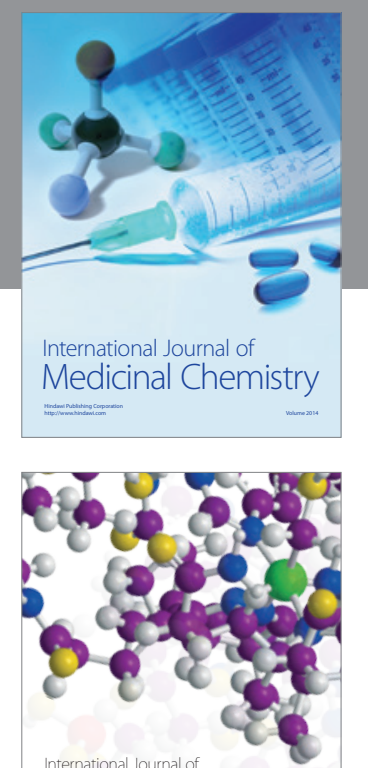

\section{Carbohydrate} Chemistry

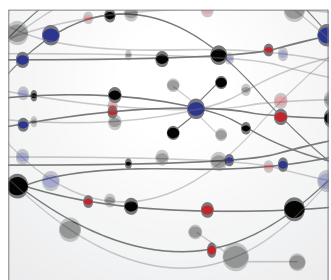

The Scientific World Journal
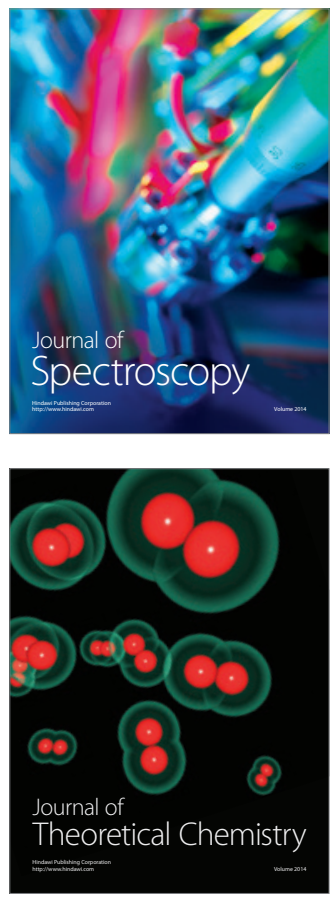
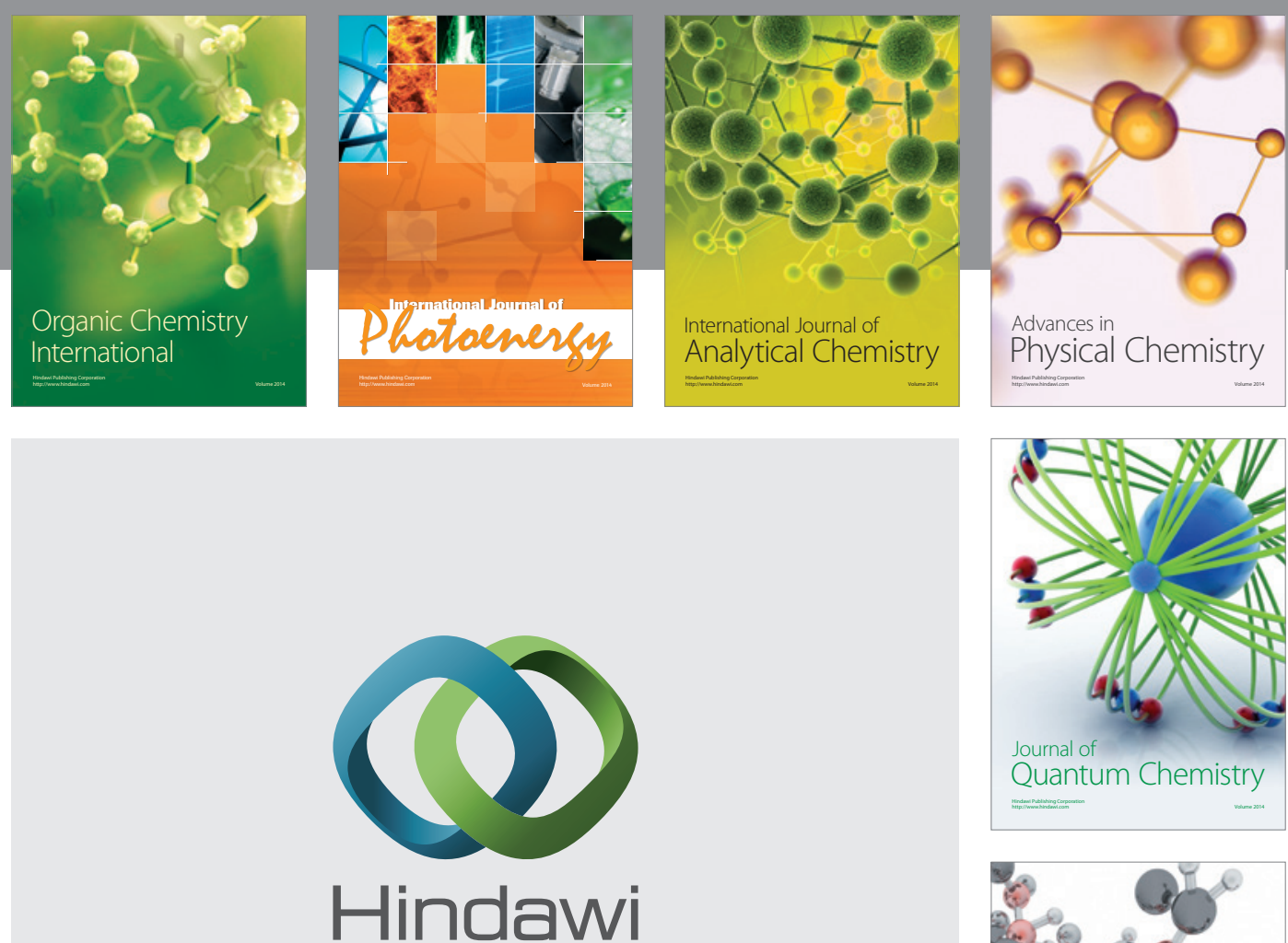

Submit your manuscripts at

http://www.hindawi.com

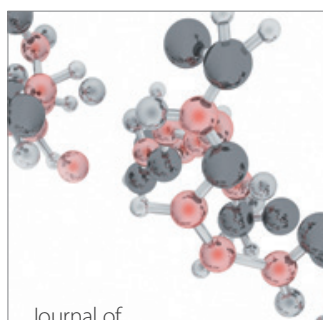

Analytical Methods

in Chemistry

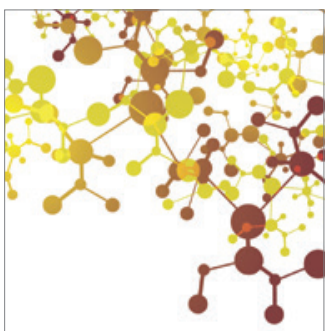

Journal of

Applied Chemistry

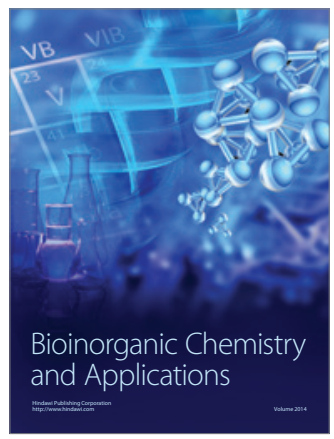

Inorganic Chemistry
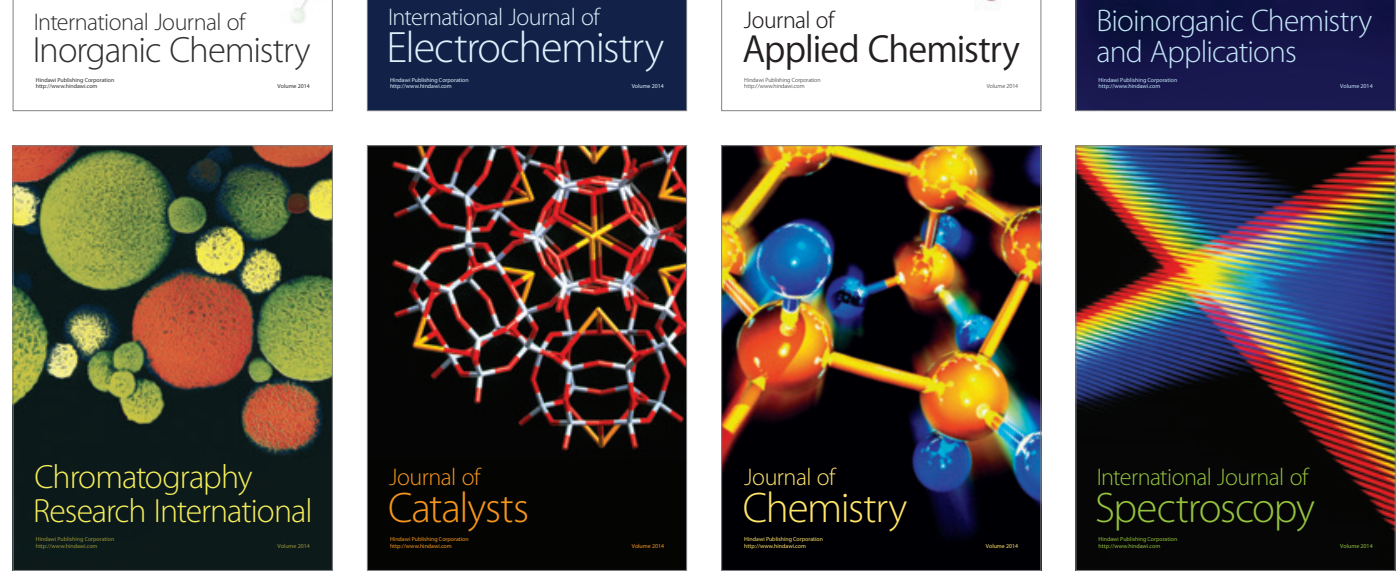